\title{
Н.С. Малышева
}

\section{США И НАЧАЛО ФУНКЦИОНИРОВАНИЯ ЕВРОПЕЙСКОГО ОБЪЕДИНЕНИЯ УГЛЯ И СТАЛИ (1952-1957 гг.)}

\begin{abstract}
Статья посвящена проблеме взаимодействия США и первой интеграционной группировки Западной Европы Европейского объединения угля и стали (ЕОУС). На основе документов Государственного департамента США и воспоминаний американских политических деятелей автор исследует проблему соответствия принципов общего рынка угольной и сталелитейной продукции экономическим и политическим интересам США в 1950-е гг. Рассматривается вопрос о выполнении европейскими странами заложенных в договоре об учреждении ЕОУС антикартельных положений и попытках американского правительства содействовать их реализации.

Ключевые слова: внешняя политика США; план Шумана; экономическая либерализация; трансатлантические отношения.
\end{abstract}

Важными вехами, обозначившими начало европейских интеграционных процессов XX в., стало подписание весной 1951 г. и вступление в силу летом 1952 г. Договора об учреждении Европейского объединения угля и стали $($ ЕОУС). Его задачами являлись снятие таможенных ограничений в торговле продукцией сталелитейной и угледобывающей промышленности, создание общего рынка тяжелой промышленности шести западноевропейских стран, содействие полной занятости в этой отрасли, а также повышение уровня жизни населения стран-участниц. Реализации Договора о ЕОУС предшествовали напряженные переговоры между Францией, ФРГ, Италией, Нидерландами, Бельгией и Люксембургом, предусматривающие урегулирование таких вопросов, как франко-германские отношения, антикартельное законодательство, статус важнейшего европейского металлургического пула - Рура и ряд других вопросов. Серьезную дипломатическую поддержку оказали США, рассматривавшие будущее интеграционное объединение как способ разрешить кризисные явления в европейской экономике и как средство франко-германского урегулирования. В то же время дальнейшее взаимодействие Соединенных Штатов с новой организацией складывалось неоднозначно.

В отечественной и зарубежной историографии сюжет о политике США в отношении ЕОУС на начальном этапе его функционирования, как правило, не является предметом отдельного исследования. Тем не менее в существующих работах, посвященных роли США в развитии европейской интеграции, отмечается тесная связь между американской поддержкой плана Шумана и его реализацией. При этом взаимодействие американского правительства со странами-участницами плана Шумана рассматривается как часть европейской политики США [1-8] либо как внешний фактор европейской интеграции [9-13]. В работах, посвященных политике США в отношении европейской интеграции, ЕОУС представлено наряду с другими интеграционными проектами - Европейское оборонительное сообщество, Евратом, Европейское экономическое сообще- ство и т.д. При этом первое интеграционное объединение, предусматривавшее более «скромные» задачи наднациональное управление угольной и сталелитейной промышленностью, несколько меркнет на фоне последующего создания общего рынка. Таким образом, изучение взаимодействия США с ЕОУС в первые годы его деятельности представляют большой научный интерес. Соответствовала ли работа Единого европейского рынка угля и стали экономическим и политическим интересам Соединенных Штатов?

Идея либерализации международной торговли являлась основополагающей в послевоенной экономической политике США. Либеральные принципы торговли должны были быть в первую очередь применены к разрушенной экономике Европы, где в довоенные годы преобладали протекционизм и стремление к созданию закрытых торговых блоков. Для этого еще в 1940-х гг. было подписано Генеральное соглашение по тарифам и торговле, а также учрежден Международный валютный фонд. Предоставление экономической помощи странам Западной Европы в рамках плана Маршалла (1948-1952 гг.) также было обусловлено снижением таможенных тарифов и увеличением импортных квот. План Шумана, озвученный 9 мая 1950 г., должен был внести свой вклад в развитие свободной торговли, поскольку предполагал создание конкурентной среды для производителей угля и стали, а общий рынок угля и стали должен был воплотить основную задачу экономической либерализации снятие таможенных барьеров. В учредительном договоре Европейского объединения угля и стали также содержались антикартельные статьи, запрещающие соглашения между предприятиями, направленные на установление цен, контроль над производством и инвестициями, раздел рынков, потребителей или источников продукции [14]. Начиная с 1950 г. американские эксперты консультировали Ж. Монне в основном по вопросам антитрестового законодательства. Выражаясь словами британского историка Дж. Киллика, план Шумана, будучи французской инициативой, был «американским по своему духу» [15. Р. 144]. 
В то же время формирование общего рынка угля и стали выглядело своеобразным экспериментом, не имеющим примеров в экономической истории. К тому же у американских политиков присутствовали опасения, что, несмотря на антикартельные статьи, в среде европейских промышленников очень прочно укоренилась идея воссоздания стального и угольного картеля. Накануне вступления в силу Договора о ЕОУС в июле 1952 г. в американском правительстве развернулась дискуссия о будущем формате отношений США с создаваемой организацией и о возможных сложностях, с которыми они могут столкнуться. Свои соображения высказал Отдел по европейским региональным вопросам в лице заместителя директора Дж. Парсонса. Первой проблемой он обозначил сохраняющуюся опасность обхода европейскими странами антикартельного законодательства и формирования картельной системы производства и продаж. Во-вторых, Парсонс предполагал, что европейские страны будут настаивать на смягчении или полной отмене принятых ими ранее в рамках ГАТТ обязательств, для того чтобы снизить внутренние торговые пошлины, оставив внешние тарифы на прежнем уровне. В связи с этим для наблюдения за функционированием ЕОУС Дж. Парсонс предлагал назначить постоянного представителя США при Высшем руководящем органе, сведущего в вопросах антикартельного законодательства, но не обладающего, впрочем, каким-либо официальным статусом при ЕОУС. Такой статус позволил бы избежать упреков в давлении на европейских союзников, при этом сохраняя «руку на пульсе» европейской интеграции. Немаловажным было то, что отсутствие официально прикрепленного к ЕОУС чиновника позволило бы избежать и финансовых обязательств со стороны США [16. Р. 86-87].

Вопрос о финансировании американской стороной ЕОУС действительно обсуждался в Государственном департаменте, и единого мнения во внешнеполитическом ведомстве США не было. Еще в 1951 г. Администрация по экономическому сотрудничеству предлагала выделить 350 млн долларов для обеспечения деятельности Высшего руководящего органа и краткосрочной поддержки промышленных предприятий Западной Европы [17. Р. 518-519]. С другой стороны, эксперты Отдела по европейским региональным вопросам считали, что для дальнейшего развития европейской интеграции ЕОУС должно показать свою устойчивость и самостоятельность. Предоставление помощи со стороны США будет поощрять чрезмерную зависимость Европы от США и подпитывать антиамериканские настроения [16. Р. 87]. Схожего мнения придерживался специальный представитель США в Европе У. Дрэйпер: нельзя настраивать европейцев на мысли о том, что весь успех ЕОУС должен зависеть от материальной поддержки США [Ibid. P. 105-106]. Поскольку начало работы институтов ЕОУС совпало с ведением переговоров об учреждении Европейского оборонительного сообщества, вопрос о финансировании в 1952 г. был отложен.
Наконец, еще одним аспектом взаимоотношений США и ЕОУС являлась перспектива возможной конкуренции европейской и американской продукции на стальном и угольном рынках. Сталелитейные компании США скептически рассматривали возможности расширения экспорта американской продукции в Западную Европу в основном из-за высоких транспортных расходов и низкой покупательской способности европейских стран в послевоенное время. Будучи ориентированными на внутренний рынок, а также на страны Латинской Америки, в 1945-1955 гг. поставки сталелитейной продукции США в страны ЕОУС составляли 7\% от всего экспорта [18. Р. 63]. В свою очередь, эксперты Консультативного совета по вопросам совместной обороны при Президенте полагали, что американская экономика слишком устойчива, чтобы рост европейского импорта представлял угрозу отечественным производителям. После окончания Второй мировой войны США оказались безусловным рекордсменом в металлургической промышленности, обеспечивая 45\% мирового производства стали. Пик послевоенного производства стали пришелся в США на 1951 г., при этом спрос на продукцию был обусловлен как внутренней потребностью американской экономики, так и военными расходами, возросшими в связи с началом войны в Корее. На первые позиции выдвинулась основанная еще в 1901 г. «ЮС Стил», которая обеспечивала 30\% всего производства стали в США. Вместе с тем госсекретарь США Д. Ачесон не исключал некоторых рисков для американской экономики, однако считал, что для укрепления стратегической альянса с Западной Европой придется пойти на уступки [19. Р. 613; 20. Р. 202].

Таким образом, накануне учреждения Европейского объединения угля и стали в американском правительстве в общих контурах были определены следующие подходы: отслеживать соблюдение странами Западной Европы антикартельного законодательства, не торопиться с предоставлением финансовой помощи, но при этом безоговорочно поддерживать становление общего рынка. 24-25 июля 1952 г. в Париже прошло двухдневное совещание министров стран - участниц плана Шумана, завершившееся вступлением в силу учредительного Договора. США стали первым государством, признавшим новую организацию в августе 1952 г. В Брюсселе было открыто Представительство США при ЕОУС, а в Вашингтоне учреждено европейское представительство организации.

10 февраля 1953 г. официально начал функционировать общий рынок угля, железной руды и лома. Европейским предприятиям был предоставлен 5-летний переходный период до февраля 1958 г., в течение которого они должны были адаптироваться к новым условиям наднационального управления. Шесть странучастниц также взяли на себя обязательство ежегодно предоставлять в ГАТТ отчет о выполнении условий Договора. Таким образом, помимо наблюдения за созданием общего рынка угля и стали со стороны пред- 
ставителя США (которым с 1953 по 1956 г. являлся бывший посол США во Франции Д. Брюс), мониторинг был возложен и на Генеральное соглашение по тарифам и торговле.

Переход к новым условиям функционирования угольного и сталелитейной рынка сопровождался сложностями. Уже осенью 1953 г. Отдел по экономической защите и торговой политике Госдепартамента США обратил внимание на то, что страны ЕОУС нарушают статьи договора, вступив в фактический картельный сговор. Так, в октябре 1953 г. Бельгия и ФРГ установили ограничения на импорт дешевого американского угля. В ответ на протест американской стороны, высказанный в частном порядке, бельгийское и западногерманское правительства утверждали, что данный вопрос уполномочен решать Высший руководящий орган [16. Р. 372]. Американская сторона сочла нежелательным выносить этот вопрос на обсуждение в ГАТТ, предпочтя неформальное обсуждение этой проблемы с председателем Высшего руководящего органа ЕОУС Ж. Монне.

Особую важность это приобрело на фоне затянувшейся ратификации Договора об учреждении Европейского оборонительного сообщества. Опасение того, что под угрозой могут оказаться и дальнейшие шаги по экономической западноевропейской интеграции, заставило Правительство США вернуться к отложенному ранее вопросу о финансовой поддержке ЕОУС. В частности, на этом настоял госсекретарь Дж. Даллес, полагая, что финансовая помощь прежде всего необходима Высшему руководящему органу [Ibid. P. 378]. Для эффективного функционирования ЕОУС в апреле 1954 г. Экспортно-импортный банк США предоставил кредит в 100 млн долларов.

Поводом для нового беспокойства стал второй ежегодный отчет о работе Европейского объединения угля и стали, представленный на девятой сессии ГАТТ 1 февраля 1955 г. [20]. По его итогам 5 февраля 1955 г. глава Совета по внешнеэкономической политике сенатор Дж. Додж направил в Госдепартамент меморандум, в котором обращал внимание на открытое нарушение странами ЕОУС антикартельного законодательства. Примерами такого нарушения были согласование производителями экспортных цен, распределение рынков сбыта, централизованная закупка лома. Сенатор указывал, что предоставлением кредита США косвенно под- держали такие действия, «противоречащие правилам и принципам, применяемым в американской промышленности» [21. Р. 262]. По мнению Доджа, в данном случае целесообразным было бы пересмотреть политику американского правительства в отношении Объединения.

В ответ на меморандум Дж. Доджа был подготовлен доклад Государственного департамента США, в котором эксперты признавали наличие ценового сговора между европейскими производителями. В то же время отмечалась успешная деятельность Высшего руководящего органа ЕОУС по созданию конкурентной среды и борьбе с ограничительными практиками [21. Р. 263-266]. Позже, в октябре 1955 г., Госдепартамент подготовил еще один доклад, в котором давал положительную оценку предпринимаемым в ЕОУС антитрестовым мерам. Подчеркивалось, что предоставленный США кредит был направлен на модернизацию 59 угольных предприятий, ни одно из которых не было замечено в нарушении антикартельного законодательства [21. Р. 342].

Таким образом, во внешнеполитическом ведомстве США сложилось особое видение происходящих на общем рынке угля и стали процессов: в переходный период ЕОУС нужно подходить с пониманием, не ожидая быстрого перехода от привычного европейским предприятиям монополизма к экономическому либерализму. Нарушение странами - участницами ЕОУС статей, запрещавших устанавливать национальный контроль над производством и инвестициями, ценами и рынками носило регулярный характер. К примеру, для местных перевозчиков действовали более низкие железнодорожные тарифы, чем для иностранных, а компании продолжали продавать продукцию по своей цене [22. Р. 175-177; 23. Р. 280]. Попытки Высшего руководящего органа бороться с ограничительными практиками поддерживались Соединенными Штатами, но саботировались европейскими компаниями и правительствами. Таким образом, экономический результат первых лет функционирования ЕОУС оказался намного скромнее, чем можно было ожидать. Намеченные американским правительством планы либерализации западноевропейского рынка так и не были реализованы. В то же время в условиях противостояния с Советским Союзом большее значение приобретал вопрос об обеспечении единства европейских стран и консолидации западных демократий, нежели вопрос об экономических выгодах ЕОУС для американской торговли.

\section{ЛИТЕРАТУРА}

1. Eichengreen B. The European Economy Since 1945: Coordinated Capitalism and Beyond. Princeton : Princeton University Press, 2008. 520 p.

2. Baldwin R., Wyplosz S. The Economics of European Integration. New York : McGraw Hill Inc., 2015. 560 p.

3. Dobson A., Marsh S. The US Foreign Policy since 1945. Second Edition. New York : Routledge, 2006. 283 p.

4. Gillingham J. Coal, Steel and Rebirth of Europe, 1945-1955: The Germans and French from Ruhr Conflict to Economic Community. New York : Cambridge University Press, 1991. 392 p.

5. Hogan M. The Marshall Plan. America, Britain, and the reconstruction of Western Europe, 1947-1952. New York : Cambridge University Press, 1987. $482 \mathrm{p}$.

6. Lundestad G. "Empire" by Integration: The United States and European Integration, 1945-1997. New York : Oxford University Press, 1998. 200 p.

7. Milward A. The Reconstruction of Western Europe, 1945-1951. Berkely : University of California Press, 1984.458 p.

8. Борко Ю.А. От европейской идеи - к единой Европе. М. : Деловая литература, 2003. 464 с.

9. Лисовский В.И. «План Шумана»- орудие агрессии американских империалистов // Советское государство и право. 1951. № 7. С. 62-68.

10. Лекаренко О.С. США и процесс объединения стран Западной Европы в 1955-1963 гг. Томск : Изд-во Том. ун-та, 2012.408 с. 
11. Селезнев Г.К. «Общий рынок» и США. М. : Наука, 1962. 166 с.

12.Симмс Б. Европа. Борьба за господство : пер. с англ. М. : АСТ, 2017. 736 с.

13. Договор об учреждении Европейского объединения угля и стали // Европейский Союз: прошлое, настоящее, будущее : в 6 т. Т. I: Договоры, учреждающие Европейские сообщества. М. : Международная издательская группа «Право», 1994. С. 21-94.

14. Killick J. The United States and European Reconstruction, 1945-1960. London : Fitzroy Dearborn Publishers, 2000.209 p.

15. Foreign Relations of the United States (FRUS). 1952-1954. Vol. VI. Part I: Western Europe and Canada. Wash., D.C. : U.S. Government Printing Office, 1986. 1737 p.

16. FRUS. 1951. Vol. IV. Europe: Political and Economic Developments (in two parts). Wash., D.C. : U.S. Government Printing Office, 1985. 1912 p.

17. Stein J. Running Steel, Running America: Race, Economic Policy and the Decline of Liberalism. Chapel Hill : The University of North Carolina Press, $1998.410 \mathrm{p}$.

18. Acheson D. Present at the Creation: My Years in the State Department. New York : Norton, 1969. 798 p.

19. Murphy R. Diplomat among Warriors. New York : Doubleday, 1964. 462 p.

20. Second Annual Report of the Member States of the European Coal and Steel Community. URL: https://docs.wto.org/gattdocs/q/GG/GATT/217.PDF

21. FRUS 1955-1957. Vol. IV. Western European Security and Integration. Wash., D.C. : U.S. Government Printing Office, 1986.659 p.

22. Diebold W. The Schuman Plan: a Study in Economic Cooperation, 1950-1959. New York : Praeger, 1959.755 p.

23. Gehrels F. The Economic Gains of European Integration// The Journal of Political Economy. 1955. Vol. 63, № 4 (Aug.). P. $275-292$.

Nina S. Malysheva. Altai State University (Barnaul, Russia). E-mail: nina.barnaul@gmail.com

THE USA AND THE BEGINNING OF THE EUROPEAN COAL AND STEEL COMMUNITY (1952-1957)

Keywords: US foreign policy; the Schuman Plan; economic liberalization; transatlantic relationship.

The article is devoted to the US policy toward the European Coal and Steel Community (the ECSC) at the first stage of its establishment. The objective of the study is to analyze economic and political motives of the US government in supporting the ECSC in 1950s, which set up supranational institutions for the fields of coal and steel in Western Europe. The study is based on historical sources, such as documents of the US State Department and American diplomats' memoirs. The author concludes that the USA encouraged the creation of the European Coal and Steel Community in 1951 not because of political matters only, but also in order to promote a common market, free of trade barriers. Most American supporters of the ECSC project believed that integration would expand beyond coal and steel and it would serve as a first step toward deeper European integration. At the same time, there were some concerns among American diplomats that the participating countries would try to rebuild pre-war cartels in Europe. In that regard, American experts insisted on the anti-cartel provisions to be included in the Treaty of 1951. The European Coal and Steel Community created a framework of rules that banned cartels, eliminated subsidies and forbade price discrimination. The High Authority of the ECSC was authorized to deal with restrictive arrangements and to take an anti-trust action. However, in 1950s the ECSC rules were regularly ignored by European firms and governments. In fact, the steel producers of the European Coal and Steel Community have established a cartel to fix minimum prices for export from the Community. Although the US government tried to discuss the case of the export cartel with the ECSC' members, no positive results were accomplished.

The author came to conclusion that the USA's attempts to support the High Authority in the dismantling of the cartels have failed. European governments were concerned with facilitating national industrial growth, not with American plans of economic liberalization. However, while the Community's progress in combating restrictive practice had been slow, American government continued to support European integration on the whole. That support was indirect, because American intervention was politically risky and could be seen as an American attempt to reshape Europe, rather than a European project. But in second half of 1950s, after the collapse of the European Defense Community, the US government became more active in promoting further economic integration.

\section{REFERENCES}

1. Eichengreen, B. (2008) The European Economy Since 1945: Coordinated Capitalism and Beyond. Princeton: Princeton University Press.

2. Baldwin, R. \& Wyplosz, S. (2015) The Economics of European Integration. New York: McGraw Hill Inc.

3. Dobson, A. \& Marsh, S. (2006) The US Foreign Policy since 1945. 2nd ed. New York: Routledge.

4. Gillingham, J. (1991) Coal, Steel and Rebirth of Europe, 1945-1955: The Germans and French from Ruhr Conflict to Economic Community. New York: Cambridge University Press.

5. Hogan, M. (1987) The Marshall Plan. America, Britain, and the reconstruction of Western Europe, 1947-1952. New York: Cambridge University Press.

6. Lundestad, G. (1998). "Empire” by Integration: The United States and European Integration, 1945-1997. New York: Oxford University Press.

7. Milward, A. (1984) The Reconstruction of Western Europe, 1945-1951. Berkely: University of California Press.

8. Borko, Yu.A. (2003) Ot evropeyskoy idei-k edinoy Evrope [From the European idea - to a united Europe]. Moscow: Delovaya literatura.

9. Lisovsky, V.I. (1951) "Plan Shumana" - orudie agressii amerikanskikh imperialistov [The "Schumann's Plan" - an instrument of aggression by the American imperialists]. Sovetskoe gosudarstvo i pravo. 7. pp. 62-68.

10. Lekarenko, O.S. (2012) SShA i protsess ob"edineniya stran Zapadnoy Evropy v 1955-1963 gg. [The USA and unification in Western Europe in 1955-1963]. Tomsk: Tomsk State University.

11. Seleznev, G.K. (1962) "Obshchiy rynok" i SShA [“Common Market” and the United States.]. Moscow: Nauka.

12. Simms, B. (2017) Evropa. Bor'ba za gospodstvo [Europe. The Struggle for Supremacy]. Translated from English by V. Zhelninov. Moscow: AST.

13. The EU. (1994) Dogovor ob uchrezhdenii Evropeyskogo ob"edineniya uglya i stali [Treaty on the Establishment of the European Coal and Steel Community]. In: Borko, Yu.A. (ed.) Evropeyskiy Soyuz: proshloe, nastoyashchee, budushchee [European Union: Past, Present, Future]. Vol. 1. Moscow: Pravo. pp. 21-94.

14. Killick, J. (2000) The United States and European Reconstruction, 1945-1960. London: Fitzroy Dearborn Publishers.

15. The USA. (1986) Foreign Relations of the United States. Vol. 6. Washington, D.C.: U.S. Government Printing Office.

16. The USA. (1985) Foreign Relations of the United States. Vol. 4. Washington, D.C.: U.S. Government Printing Office.

17. Stein, J. (1998) Running Steel, Running America: Race, Economic Policy and the Decline of Liberalism. Chapel Hill: The University of North Carolina Press.

18. Acheson, D. (1969) Present at the Creation: My Years in the State Department. New York: Norton.

19. Murphy, R. (1964) Diplomat among Warriors. New York: Doubleday.

20. The EU. (n.d.) Second Annual Report of the Member States of the European Coal and Steel Community. [Online] Available from: https://docs.wto.org/gattdocs/q/GG/GATT/217.PDF

21. The USA. (1986) Foreign Relations of the United States. Vol. 4. Washington, D.C.: U.S. Government Printing Office.

22. Diebold, W. (1959) The Schuman Plan: a Study in Economic Cooperation, 1950-1959. New York: Praeger.

23. Gehrels, F. (1955). The Economic Gains of European Integration. The Journal of Political Economy. 63(4). pp. $275-292$. 